\title{
Isolation and characterization of a novel $68000-M_{\mathrm{r}} \mathrm{Ca}^{2+}$-binding protein of lymphocyte plasma membrane
}

\author{
Raymond J. OWENS and Michael J. CRUMPTON \\ Imperial Cancer Research Fund Laboratories, P.O. Box 123, Lincoln's Inn Fields, London WC2A 3PX, U.K.
}

(Received 17 November 1983/Accepted 14 December 1983)

\begin{abstract}
A $68000-M_{\mathrm{r}}$ protein is a major component of a Nonidet P-40-insoluble fraction of lymphocyte plasma membrane prepared from human B lymphoblastoid cells (BRI 8) and pig mesenteric lymph nodes. The association of the protein with the detergentinsoluble complex depends on free $\mathrm{Ca}^{2+}$ concentrations of greater than $10 \mu \mathrm{M}$. The human and pig $68000-M_{\mathrm{r}}$ proteins were purified and appear to be homologous on the basis of amino acid composition and peptide mapping. The protein is monomeric, has pI5.8 and a single high-affinity $\mathrm{Ca}^{2+}$-binding site $\left(K_{\mathrm{D}} 1.2 \mu \mathrm{M}\right)$. The results are discussed in terms of the possible role of the $68000-M_{\mathrm{r}}$ protein as an intracellular $\mathrm{Ca}^{2+}$ receptor in lymphocytes.
\end{abstract}

Changes in the cytoplasmic concentration of $\mathrm{Ca}^{2+}$ have been implicated in the regulation of many cellular processes, including motility, mitogenesis and intermediary metabolism. The effects of $\mathrm{Ca}^{2+}$ appear to be mediated by its interaction with specific $\mathrm{Ca}^{2+}$-binding proteins (Kretsinger, 1979). There is considerable evidence that $\mathrm{Ca}^{2+}$ dependent regulators are involved in the control of the cytoskeleton in non-muscle cells (Dedman et al., 1979). A number of proteins have been characterized that interact with actin in a $\mathrm{Ca}^{2+}$. dependent manner, e.g. HeLa-cell and platelet $\alpha$ actinins, which cause the bundling of microfilaments (Burridge \& Feramisco, 1981; Rosenberg et $a l .$, 1981), and gelsolin from macrophages, which causes microfilament shortening (Yin \& Stossel, 1981). Another class of actin-binding proteins, represented by villin from intestinal epithelial cells, appears to either fragment or cross-link actin microfilaments depending on the free $\mathrm{Ca}^{2+}$ concentration (Bretscher \& Weber, 1980a). Polymerization studies on microtubules have demonstrated that $\mathrm{Ca}^{2+}$ inhibits tubulin assembly in unfractionated extracts in vitro (Weisenberg, 1972; Haga et al., 1974) and in vivo (Schliwa, 1976), although tubulin does not bind $\mathrm{Ca}^{2+}$ itself.

$\mathrm{Ca}^{2+}$ appears to regulate many cellular functions via the ubiquitous $\mathrm{Ca}^{2+}$-binding protein calmodulin (Klee et al., 1980). Calmodulin-dependent

Abbreviations used: SDS, sodium dodecyl sulphate; Dulbecco's PBS, Dulbecco's phosphate-buffered saline medium. myosin light-chain kinases, which regulate the activity of the actomyosin ATPase in smooth muscle, have been identified in non-muscle cells (Klee et al., 1980). Also, the presence of calmodulin in the highly organized cytoskeletal complex of brush-border microvilli has been demonstrated (Howe et al., 1980). In addition, calmodulinbinding proteins have been identified in this system (Glenney \& Weber, 1980; Glenney et al., 1982), and a role for $\mathrm{Ca}^{2+}$ in maintaining the structural integrity of the brush-border cytoskeleton has been proposed (Glenney et al., 1980). The interaction of erythrocyte spectrin with actin via polypeptide 4.1 in vitro appears to be $\mathrm{Ca}^{2+}$ dependent (Fowler \& Taylor, 1980). In addition, the $\alpha$-subunit of spectrin and its analogues in nonerythroid cells also appears to bind calmodulin (Glenney et al., 1982). $\mathrm{Ca}^{2+}$ may thus also be involved in the organization of the membranecytoskeleton system of erythrocytes.

In the preceding paper, a detergent-insoluble complex of polypeptides associated with purified preparations of lymphocyte plasma membrane was described (Davies et al., 1984). The detergentinsoluble complex prepared from human lymphocyte plasma membrane comprised three major polypeptides, with $M_{\mathrm{r}} 120000,68000$ and 45000 , together with several more minor polypeptides, including a pair with $M_{\mathrm{r}} 33000$ and 28000 . A qualitatively similar complex was obtained from pig lymphocyte plasma membrane, although the $120000-M_{\mathrm{r}}$ polypeptide was less well represented. With the exception of the $45000-M_{\mathrm{r}}$ polypeptide, 
the major polypeptides of the complex occurred exclusively in the detergent-insoluble fraction of the plasma membrane. It was suggested that this detergent-insoluble complex represented a submembranous cytoskeleton in lymphocytes analogous to that found in erythrocytes (Branton et al., 1981). In view of the apparent role of $\mathrm{Ca}^{2+}$ in regulating the organization of cytoskeletal structures, we have investigated the effect of $\mathrm{Ca}^{2+}$ concentration on the lymphocyte membrane-cytoskeleton system. In the present paper we show that the association of the $68000-M_{\mathrm{r}}$ polypeptide with the lymphocyte membrane-cytoskeletal complex is $\mathrm{Ca}^{2+}$-dependent and provide evidence that the isolated protein binds $\mathrm{Ca}^{2+}$. A preliminary report of some of this work has been published (Owens \& Crumpton, 1983).

\section{Materials and methods}

\section{Cells}

The human B lymphoblastoid cell line BRI 8 was cultured in RPMI 1640 medium containing penicillin $(100$ units $/ \mathrm{ml})$ and streptomycin $(50 \mu \mathrm{g} / \mathrm{ml})$ and supplemented with $10 \%(\mathrm{v} / \mathrm{v})$ foetal-calf serum (Flow Laboratories, Irvine, Ayrshire, Scotland, U.K.). Pig mesenteric lymph nodes were obtained from a local commercial abattoir (British Beef, Watford, Herts., U.K.).

\section{Preparation and Nonidet P-40 extraction of plasma membrane}

Plasma membrane was prepared from BRI 8cell suspensions and from pig mesenteric lymph node as described previously by Crumpton \& Snary (1974) and Snary et al. (1976). Cells were homogenized in either Dulbecco's PBS (comprising $10 \mathrm{~mm}$-sodium phosphate buffer, $\mathrm{pH} 7.2$, $0.17 \mathrm{M}-\mathrm{NaCl}, 3 \mathrm{~mm}-\mathrm{KCl}, 1 \mathrm{mM}-\mathrm{CaCl}_{2}$ and $1 \mathrm{~mm}-$ $\mathrm{MgCl}_{2}$ ) or Dulbecco's PBS without added $\mathrm{CaCl}_{2}$ and $\mathrm{MgCl}_{2}$. Dulbecco's PBS was routinely used for plasma-membrane preparation. Proteolysis was inhibited by the addition of phenylmethanesulphonyl fluoride and iodoacetamide to the cell suspensions and tissue homogenates, to final concentrations of $1 \mathrm{~mm}$ and $10 \mathrm{~mm}$ respectively.

The detergent-insoluble fraction of lymphocyte plasma membrane, referred to below as the ' $20 \mathrm{k}$ pellet', was prepared as described in the preceding paper (Davies et al., 1984); a final concentration of $1 \%$ (v/v) Nonidet P-40 was used to extract the purified plasma-membrane preparations.

\section{SDS/polyacrylamide-gel electrophoresis}

Samples were analysed on $10 \%(\mathrm{w} / \mathrm{v})$ polyacrylamide slab gels in $0.1 \%$ SDS in $25 \mathrm{~mm}$-Tris $/ 192 \mathrm{~mm}$ glycine buffer, $\mathrm{pH} 8.3$, as described by the method of Laemmli (1970). Two-dimensional isoelectric-
focusing-SDS/polyacrylamide-gel electrophoresis was carried out as described by O'Farrell (1975). The $\mathrm{pH}$ gradient for the first dimension was generated by using equal volumes of Ampholines (LKB, Bromma, Sweden) pH 3.5-10 and pH 5-7. A Pharmacia flat-bed apparatus (FBE 3000) was used for isoelectric focusing. Samples were run for $3000 \mathrm{~V} \cdot \mathrm{h}$ in $5 \%(\mathrm{w} / \mathrm{v})$ polyacrylamide gels containing Ampholine pH3.5-10 and 6M-urea. $\mathrm{pH}$ gradients after isoelectric focusing were determined by cutting blank gels, run in parallel, into $0.5 \mathrm{~cm}$ segments. These were each then soaked in $1.5 \mathrm{ml}$ of distilled water and the $\mathrm{pH}$ of each eluate was measured with a pH-meter (Beckman Instruments).

Proteins in gels were detected either by Coomassie Blue staining (Owen et al., 1980) or by silver staining (Morrissey, 1981). Polypeptides were quantified by scanning densitometry with a JoyceLoebl Chromoscan 3 instrument. The following proteins were used as $M_{\mathrm{r}}$ standards: myosin heavy chain (200000), $\beta$-galactosidase (130000), phosphorylase $b(95000)$, bovine serum albumin (68000), ovalbumin (45000), glyceraldehyde-3phosphate dehydrogenase (34000), immunoglobulin light chain (25000) and cytochrome $c$ (12500).

\section{Peptide mapping}

Peptide mapping by limited proteolysis was carried out by the procedure of Cleveland et al. (1977). Polypeptide bands containing 5-10 $\mu \mathrm{g}$ of protein were excised from SDS/polyacrylamide gels and digested in the gel slices with Staphylococcus griseus proteinase (Sigma Chemicals, Poole, Dorset, U.K.) $(10-100 \mu \mathrm{g} / \mathrm{ml})$ for $30 \mathrm{~min}$ at room temperature. Peptides were resolved in SDS $/ 15 \%$ (w/v)-polyacrylamide gels containing 1 mM-EDTA and detected by silver staining.

\section{Amino acid analysis}

Protein $(10-15 \mu \mathrm{g})$ was hydrolysed in constantboiling $\mathrm{HCl}$ at $110^{\circ} \mathrm{C}$ for $24 \mathrm{~h}$. The amino acids were subjected to pre-column formation of the $o$ phthalaldehyde derivatives (Jones et al., 1981), which were then separated by reverse-phase highpressure liquid chromatography by using the Waters system.

\section{Calcium buffers}

Known concentrations of ionic $\mathrm{Ca}^{2+}$ were obtained by using calcium/EDTA buffers, the compositions of which were calculated from known dissociation constants of EDTA- $\mathrm{Ca}^{2+}$ and EDTA- $\mathrm{Mg}^{2+}$ complexes (Kim \& Padilla, 1978). Buffers for different theoretical free $\mathrm{Ca}^{2+}$ concentrations contained $5 \mathrm{~mm}-\mathrm{EDTA}, 5 \mathrm{~mm}-\mathrm{MgCl}_{2}$ and the following concentrations of $\mathrm{CaCl}_{2}$ : for $0.1 \mathrm{mM}$ $\mathrm{Ca}^{2+}, 3.5 \mathrm{mM}-\mathrm{CaCl}_{2}$; for $10 \mu \mathrm{M}-\mathrm{Ca}^{2+}, 1.65 \mathrm{mM}-$ 
$\mathrm{CaCl}_{2}$; for $1.0 \mu \mathrm{M}-\mathrm{Ca}^{2+}, 0.6 \mathrm{mM}-\mathrm{CaCl}_{2}$; for $0.1 \mu \mathrm{M}-$ $\mathrm{Ca}^{2+}, 0.15 \mathrm{~mm}-\mathrm{CaCl}_{2}$. Calcium buffers were made up in either $10 \mathrm{~mm}$-sodium phosphate buffer, $\mathrm{pH} 7.2,0.17 \mathrm{M}-\mathrm{NaCl}$ or $10 \mathrm{~mm}-\mathrm{Tris} / \mathrm{HCl}$ buffer, pH7.4.

\section{$\mathrm{Ca}^{2}+$ binding}

$\mathrm{Ca}^{2+}$-binding activity was measured by the equilibrium gel-filtration method of Hummel and Dryer (Ackers, 1973) with ${ }^{45} \mathrm{CaCl}_{2}(0.55 \mathrm{Ci} / \mathrm{mmol}$; Amersham International, Amersham, Bucks., U.K.). Purified $68000-M_{\mathrm{r}}$ protein was dialysed extensively against $10 \mathrm{mM}$-Tris/HCl buffer, $\mathrm{pH} 7.4$, containing $50 \mathrm{~mm}-\mathrm{KCl}$, at $4^{\circ} \mathrm{C}$. Samples $(0.5 \mathrm{ml})$ containing $30 \mu \mathrm{g}$ of protein were equilibrated for 60 min at $4{ }^{\circ} \mathrm{C}$ with known amounts of ${ }^{45} \mathrm{Ca}^{2+}$, which were calculated from the specific radioactivity of the ${ }^{45} \mathrm{CaCl}_{2}$, adjusted for radioactivity decay when necessary. Each sample was then gelfiltered on a Sephadex G-25 (Pharmacia, Uppsala, Sweden) column $(10 \mathrm{ml})$ pre-saturated at the same ${ }^{45} \mathrm{Ca}^{2+}$ concentration as the sample. Fractions $(0.5 \mathrm{ml})$ were collected and assayed for radioactivity by liquid-scintillation counting. The amount of protein-bound ${ }^{45} \mathrm{Ca}^{2+}$ was determined by measuring the area of the peak of radioactivity eluted from the column above the saturating baseline.

\section{Determination of protein}

Protein was determined by the method of Lowry et al. (1951), with bovine serum albumin as a standard.

\section{Results}

Purified plasma-membrane fractions were prepared from two sources of lymphocytes, namely human B lymphoblastoid cells (BRI 8) and pig mesenteric lymph nodes (comprising predominantly $\mathrm{T}$ and/or null cells on the basis that only about $10 \%$ of the cells expressed surface immunoglobulin). The lymphoblastoid cells had been transformed with Epstein-Barr virus and grew continuously in culture, whereas the pig lymphocytes were unstimulated (i.e. quiescent).

Plasma-membrane fractions were isolated by a combination of differential rate and sucrosedensity centrifugation after homogenization of the cells in either Dulbecco's PBS or Dulbecco's PBS without added $\mathrm{MgCl}_{2}$ and $\mathrm{CaCl}_{2}$. The polypeptide compositions of plasma membranes prepared in the presence of bivalent cations were identical with those of plasma membranes prepared in their absence.

\section{Nonidet P-40 extraction of plasma membrane in the presence of $\mathrm{Ca}^{2+}$ chelators}

To investigate the effect of $\mathrm{Ca}^{2+}$ on the polypeptide composition of the detergent-insoluble

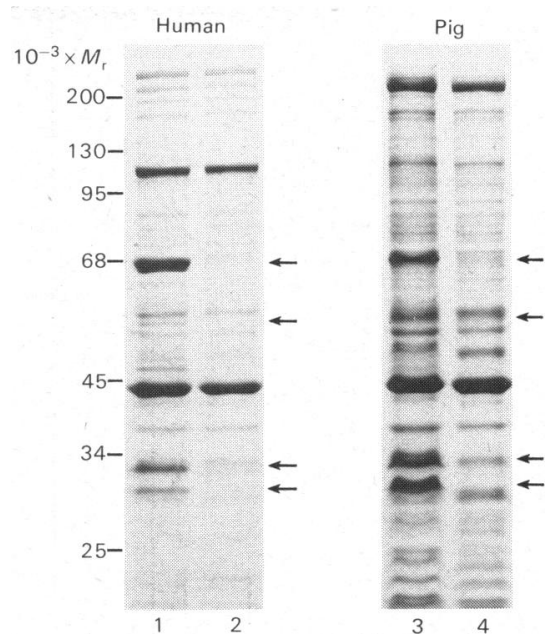

Fig. 1. Effect of $\mathrm{Ca}^{2+}$ chelators on the Nonidet P-40insoluble fraction of lymphocyte plasma membrane Plasma membranes prepared from human lymphoblastoid cells (BRI 8) and pig lymph-node lymphocytes were extracted with $1 \%$ Nonidet P-40 in Dulbecco's PBS containing either $1 \mathrm{mM}$ $\mathrm{CaCl}_{2}+1 \mathrm{mM}-\mathrm{MgCl}_{2}$ or $1 \mathrm{mM}-\mathrm{EGTA}+1 \mathrm{mM}$ $\mathrm{MgCl}_{2}$ but not $\mathrm{CaCl}_{2}$. The extracts were centrifuged at $10^{6} \mathrm{~g}$-min $(20000 \mathrm{rev} . / \mathrm{min}$ for $30 \mathrm{~min}$ in a Beckman $50.2 \mathrm{Ti}$ rotor) and the resulting detergentinsoluble residues (20k pellets) were analysed on $10 \%(\mathrm{w} / \mathrm{v})$ polyacrylamide gels in the presence of SDS. Gels were run under reducing conditions and were stained with Coomassie Blue. Human and pig 20k pellets prepared in either the presence (tracks 1 and 3) or in the absence (tracks 2 and 4) of $\mathrm{Ca}^{2+}$. The arrows indicate the polypeptides associated with $20 \mathrm{k}$ pellet in the presence of $1 \mathrm{mM}-\mathrm{Ca}^{2+}$. The $M_{\mathrm{r}}$ values of protein standards run in parallel are given on the left of the gels.

fraction, purified plasma membrane $(1 \mathrm{mg}$ of protein $/ \mathrm{ml}$ ) was extracted with $1 \%$ Nonidet $\mathrm{P}-40$ in Dulbecco's PBS containing either $1 \mathrm{mM}$ $\mathrm{CaCl}_{2}+1 \mathrm{mM}-\mathrm{MgCl}_{2}$ or $1 \mathrm{mM}-\mathrm{EGTA}+1 \mathrm{mM}-$ $\mathrm{MgCl}_{2}$ with no $\mathrm{CaCl}_{2}$ for $30 \mathrm{~min}$ at $4^{\circ} \mathrm{C}$. The polypeptide compositions of the resulting detergentinsoluble pellets prepared in the presence and in the absence of $\mathrm{Ca}^{2+}$ are shown in Fig. 1. Similar results were obtained with human and pig plasma membranes and they indicated that extraction of the plasma membrane in the presence of the $\mathrm{Ca}^{2+}$ chelator (i.e. a free $\left[\mathrm{Ca}^{2+}\right]$ of $0.1 \mu \mathrm{M}-\mathrm{Ca}^{2+}$ ) gave pellets that lacked the $68000-M_{\mathrm{r}}$ polypeptide together with the bands of $M_{\mathrm{r}} 55000,33000$ and 28000 . Identical results were obtained with $1 \mathrm{~mm}$ EDTA in place of EGTA $+\mathbf{M g C l}_{2}$. The concentration of $\mathrm{Ca}^{2+}$ required to maintain the association of the $68000-M_{\mathrm{r}}$ polypeptide with the detergent-insoluble fraction of the plasma mem- 


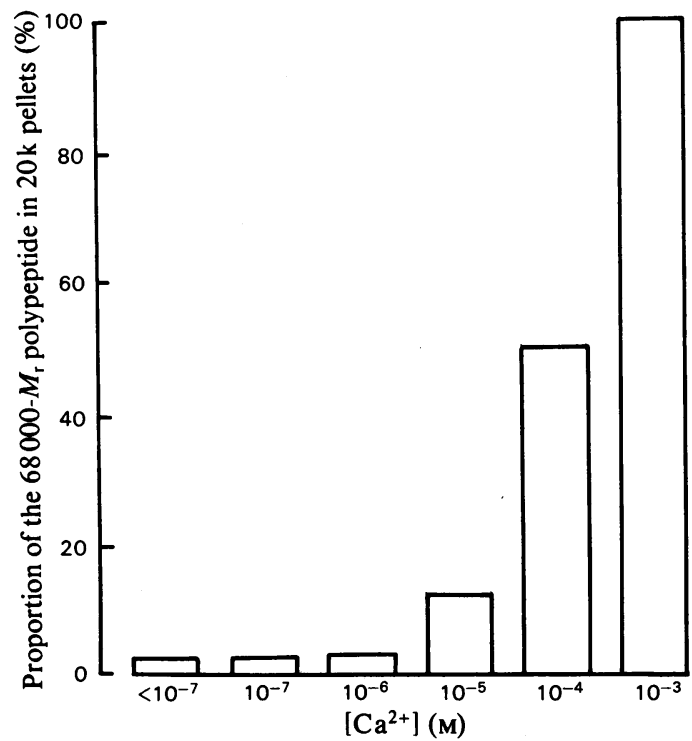

Fig. 2. Proportion of the 68000-M, polypeptide present in $20 k$ pellets prepared at different $\mathrm{Ca}^{2+}$ concentrations Samples (1 mg of protein) of plasma membrane prepared from BRI 8 cells were extracted with $1 \%$ (v/v) Nonidet P-40 solutions containing $0.1 \mu \mathrm{M}-$ $1.0 \mathrm{~mm}-\mathrm{Ca}^{2+}$. The polypeptide compositions of the resulting $20 \mathrm{k}$ pellets were analysed by electrophoresis on $10 \%$ polyacrylamide gels in the presence of SDS under reducing conditions. The amount of the $68000-M_{\mathrm{r}}$ polypeptide present in each sample was estimated by densitometric scanning of Coomassie Blue-stained gels. The results are represented as the percentages of the amount of $68000-M_{r}$ polypeptide in $20 \mathrm{k}$ pellets prepared in the presence of $1.0 \mathrm{~mm}-\mathrm{Ca}^{2+}$.

brane was then estimated. The 20k pellets were prepared by extracting plasma membrane $(1 \mathrm{mg} / \mathrm{ml})$ with Nonidet $\mathrm{P}-40$ solutions containing various concentrations of $\mathrm{Ca}^{2+}(0.1 \mu \mathrm{M}-1.0 \mathrm{mM})$. The polypeptide compositions of the pellets were then quantified by densitometric scanning of Coomassie Blue-stained gels. As shown in Fig. 2, the amount of the $68000-M_{\mathrm{r}}$ polypeptide in the $20 \mathrm{k}$ pellet was progressively diminished by extracting the plasma membrane at decreasing concentrations of $\mathrm{Ca}^{2+}$ below $1.0 \mathrm{~mm}$. Complete solubilization of the polypeptide occurred at $\mathrm{Ca}^{2+}$ concentrations of less than $10 \mu \mathrm{M}$; the residual percentage of protein represents minor polypeptides in the 20k pellet that co-migrate with the $68000-M_{\mathrm{r}}$ polypeptide (see Fig. 1).

\section{Nature of the EGTA extract}

The $68000-M_{\mathrm{r}}$ polypeptide was separated from the $20 \mathrm{k}$ pellet by making use of its $\mathrm{Ca}^{2+}$-dependent solubility. The $20 \mathrm{k}$ pellets were prepared from BRI
8 cells and pig lymphocytes in the presence of $1 \mathrm{mM}^{-\mathrm{Ca}^{2+}}$. The washed pellets were then reextracted (1 mg of protein $/ \mathrm{ml}$ ) with Dulbecco's PBS, containing $1 \%$ Nonidet P-40, 1 mM-EGTA and $1 \mathrm{mM}-\mathrm{MgCl}_{2}$ but no $\mathrm{CaCl}_{2}$ for $30 \mathrm{~min}$ at $0^{\circ} \mathrm{C}$ and centrifuged at $100000 g_{\text {av }}$, for $30 \mathrm{~min}$ at $4^{\circ} \mathrm{C}$. The supernatant was collected and concentrated by ethanol precipitation $(95 \%, v / v$, for $16 \mathrm{~h}$ at $-20^{\circ} \mathrm{C}$ ). The EGTA extract of both human (Fig. 5, track 3) and pig (Fig. 3, tracks 1 and 2) 20k pellets consisted mainly of the $68000-M_{\mathrm{r}}$ polypeptide (about $60 \%$ of the total protein, as judged by densitometric scanning), together with smaller amounts of the $55000-M_{\mathrm{r}}, 45000-M_{\mathrm{r}}, 33000-M_{\mathrm{r}}$ and $28000-M_{\mathrm{r}}$ polypeptides.

Complete release of the $68000-M_{\mathrm{r}}$ polypeptide from the 20k pellet depended on the presence of Nonidet P-40. Re-extraction of 20k pellets with Dulbecco's PBS containing EGTA and $\mathrm{MgCl}_{2}$ but no $\mathrm{CaCl}_{2}$ resulted in the solubilization of only 65 $70 \%$ of the $68000-M_{\mathrm{r}}$ polypeptide. A second reextraction of the pellets with Dulbecco's PBS containing EGTA and $\mathrm{MgCl}_{2}$ but no $\mathrm{CaCl}_{2}$ did not yield any further amounts of the polypeptide. All the remaining $68000-M_{\mathrm{r}}$ polypeptide could be extracted if the insoluble residue was then treated with Dulbecco's PBS containing EGTA, $\mathrm{MgCl}_{2}$ and $1 \%$ Nonidet $\mathrm{P}-40$ but no $\mathrm{CaCl}_{2}$. These results indicated that most of the $68000-M_{\mathrm{r}}$ polypeptide behaves as a peripheral membrane protein; a proportion, however, appears to be more tightly bound to the lipid bilayer.

In view of the co-solubilization of the $68000-M_{\mathrm{r}}$ polypeptide with those of $M_{\mathrm{r}} 55000,33000$ and 28000 , an important question was whether these polypeptides were associated in any way. As an approach to this question, samples of the EGTA extract were analysed by electrophoresis on SDS/polyacrylamide gels in the presence and in the absence of $1 \mathrm{~mm}$-dithiothreitol. No difference in the polypeptide compositions or mobilities of the extracts were observed under reducing compared with non-reducing conditions (Fig. 3, tracks 1 and 2). Thus none of the polypeptides of the EGTA extract appeared to be linked by disulphide bonds. This result also indicated that the $68000-M_{r}$ polypeptide was not serum albumin, which shows a characteristic downward shift in $M_{\mathrm{r}}$ value $(68000$ to 55000) when run on SDS/polyacrylamide gels under non-reducing conditions (Fig. 3, tracks 3 and 4). Albumin has been shown to be a component of pig but not human lymphocyte plasma membrane (Owen et al., 1980).

\section{Purification of the 68000-Mr protein}

The $68000-M_{\mathrm{r}}$ polypeptide was purified to apparent homogeneity, as judged by one-dimensional and two-dimensional SDS/polyacrylamide- 


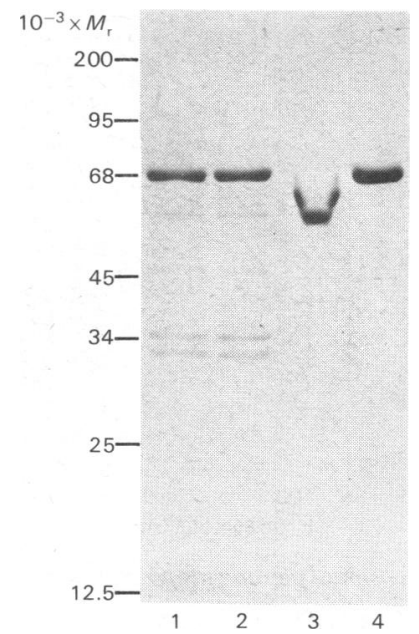

Fig. 3. SDS/polyacrylamide-gel electrophoresis of the EGTA extract under reducing and non-reducing conditions The 20k pellet, prepared from pig lymph-node lymphocyte plasma membrane, was re-extracted with EGTA as described in the legend to Fig. 2. Samples were analysed by SDS/polyacrylamide-gel electrophoresis under reducing conditions (1 mMdithiothreitol) (track 1) and non-reducing conditions (track 2). A sample of pig serum albumin was run in parallel under non-reducing (track 3 ) and reducing conditions (track 4). The gel was stained with Coomassie Blue. The $M_{\mathrm{r}}$ values of protein standards are given on the left of the gels.

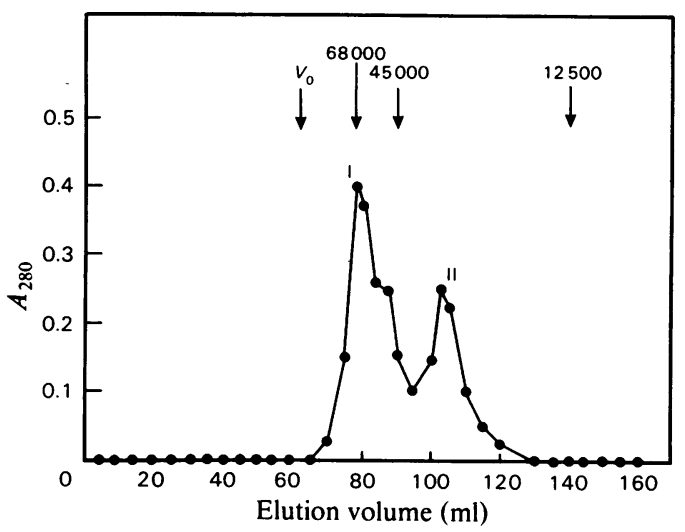

Fig. 4. Gel filtration of the EGTA extract

The EGTA extract prepared from BRI 8-cell 20k pellet was applied to a Sephacryl S-200 (Pharmacia) column $(160 \mathrm{ml})$ equilibrated in $20 \mathrm{~mm}-\mathrm{Tris} / \mathrm{HCl}$ buffer, pH 7.4. The column was eluted with the same buffer and the eluate monitored for absorption at $280 \mathrm{~nm}$. Fractions $70-80$ and $100-110$, corresponding to the two major $A_{280}$ peaks (I and II), were combined and concentrated by using an Amicon ultrafiltration cell with a PM30 membrane. The column was calibrated with the following standards: bovine serum albumin $\left(M_{\mathrm{r}} 68000\right)$, ovalbumin $\left(M_{\mathrm{r}} 45000\right)$ and cytochrome $c\left(M_{\mathrm{r}} 12500\right)$.

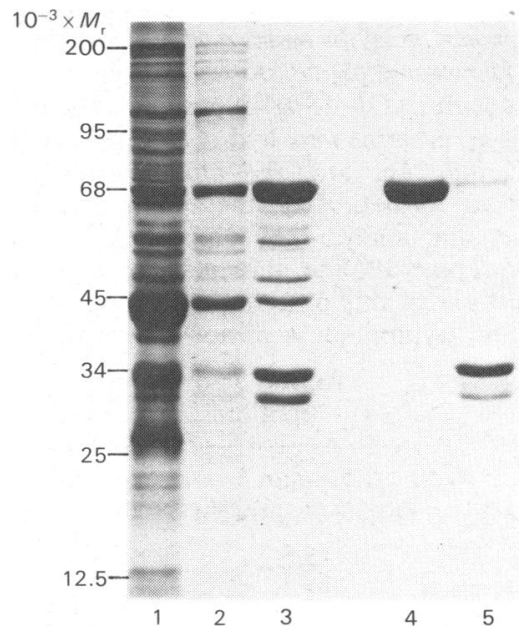

Fig. 5. SDS/polyacrylamide-gel electrophoresis of stages during the purification of the $68000-M_{r}$ protein The 20k pellet (track 2) was prepared from BRI 8cell plasma membrane (track 1) as described in the Materials and methods section. The 20k pellet was washed and re-extracted with Dulbecco's PBS containing $1 \mathrm{mM}-E G T A$ and $1 \mathrm{mM}-\mathrm{MgCl}_{2}$ but no $\mathrm{CaCl}_{2}$. The $68000-M_{\mathrm{r}}$ protein was separated from the other polypeptides of the EGTA extract (track 3) by gel filtration on a Sephacryl S-200 column. Fractions that contained the $68000-M_{\mathrm{r}}$ protein (Fig. 4, peak I, track 4) and the $33000 / 28000-M_{\mathrm{r}}$ polypeptides (peak II, track 5) were combined. All the samples were analysed by electrophoresis on $10 \%$ polyacrylamide gels in the presence of SDS under reducing conditions and stained with Coomassie Blue. The $M_{\mathrm{r}}$ values of protein standards are given on the left of the gels.

gel electrophoresis (Fig. 5, track 4, and Fig. 6), by gel filtration of the EGTA extract. The $20 \mathrm{k}$ pellet was prepared from BRI 8-cell plasma membrane and washed by centrifugation to remove Nonidet $P-40$. The pellet was then re-extracted in the presence of EGTA as described above but without the addition of Nonidet P-40, and the soluble extract was dialysed extensively against distilled water at $4^{\circ} \mathrm{C}$. The dialysed extract was freeze-dried and dissolved in $20 \mathrm{~mm}$-Tris/HCl buffer, $\mathrm{pH} 7.4$. The $68000-M_{\mathrm{r}}$ polypeptide was separated from the other components of the EGTA extract by gel filtration on Sephacryl S-200. Two major peaks of protein were eluted from the column (I and II, Fig. 4). A shoulder on the first peak suggested that it overlapped a third peak, which was not completely resolved. To obtain as homogeneous a preparation as possible, only the peak and leading fractions of peak I were combined. The polypeptide compositions of the two peaks (I and II) are shown in Fig. 5 (tracks 4 and 5). The $68000-M_{\mathrm{r}}$ polypeptide 
Table 1. Comparison of the amino acid compositions of the human and pig $68000-M_{r}$ proteins

Duplicate samples $(10-15 \mu \mathrm{g})$ of purified human and pig $68000-M_{\mathrm{r}}$ proteins were hydrolysed in $5.7 \mathrm{M}-\mathrm{HCl}$ at $110^{\circ} \mathrm{C}$ for $24 \mathrm{~h}$, and the amino acids were subjected to formation of the $o$-phthalaldehyde derivatives and analysed by high-pressure liquid chromatography. Proline and hydroxyproline are not detected with this procedure. The amounts of cysteine and tryptophan were not determined.

\begin{tabular}{ccc} 
& \multicolumn{2}{c}{$\begin{array}{c}\text { Amino acid composition } \\
\text { (mol/mol of protein) }\end{array}$} \\
\cline { 2 - 3 } Amino acid & $\begin{array}{c}\text { Human } \\
\text { 68000-M } M_{\text {r }} \text { protein }\end{array}$ & $\begin{array}{c}\text { Pig } \\
\text { 6sp }\end{array}$ \\
Asp & 84.4 & 84.4 \\
Glu & 89.1 & 92.8 \\
Ser & 56.9 & 54.1 \\
His & 38.8 & 33.8 \\
Gly & 62.9 & 66.5 \\
Thr & 48.4 & 48.3 \\
Arg & 31.1 & 33.2 \\
Ala & 64.0 & 64.7 \\
Tyr & 26.5 & 28.5 \\
Met & 16.6 & 17.7 \\
Val & 16.9 & 17.9 \\
Phe & 27.2 & 28.2 \\
Ile & 20.7 & 19.1 \\
Leu & 62.9 & 58.3 \\
Lys & 62.4 & 61.3 \\
No. & 708.8 & 709.0
\end{tabular}

was eluted from the column at the position expected for a globular protein of $M_{\mathrm{r}} 68000$. No association of this protein with any of the other polypeptides in the EGTA extract was apparent under the conditions used. The purified protein gave a single spot on two-dimensional isoelectricfocusing-SDS/polyacrylamide-gel electrophoresis at a $\mathrm{pH}$ of approx. 5.8. To obtain sufficient amounts of the $68000-M_{\mathrm{r}}$ protein for chemical analysis, $100 \mathrm{mg}$ of plasma-membrane protein was required and typically yielded $200 \mu \mathrm{g}$ of purified protein. The $68000-M_{\mathrm{r}}$ protein was purified from pig lymphocyte plasma membrane by a procedure identical with that described above.

\section{Comparison of human and pig $68000-M_{r}$ proteins}

The $68000-M_{\mathrm{r}}$ proteins purified from human BRI 8 cells and pig lymphocytes were compared in terms of isoelectric points, amino acid compositions and partial-proteolysis peptide maps. On isoelectric focusing, both the human and pig $68000-M_{\mathrm{r}}$ proteins gave a cluster of bands that possessed pI values of 5.7-5.9. This result is consistent with that obtained by two-dimensional gel analysis, although the isoelectric variants were not resolved, probably owing to overloading of the gel. The identical isoelectric points of the human and

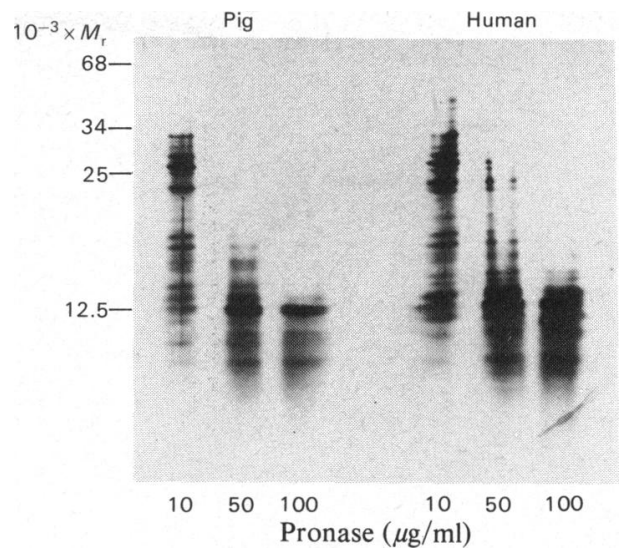

Fig. 6. One-dimensional peptide mapping of pig and human 68000-M, proteins

EGTA extracts were prepared from human and pig 20k pellets, and samples were subjected to electrophoresis on a $10 \%$ polyacrylamide gel in the presence of SDS. The gels were lightly stained with Coomassie Blue, and the $68000-M_{\mathrm{r}}$ polypeptide bands were cut out of the gel. The protein in the gel slices was digested with Staphylococcus griseus proteinase $(10-100 \mu \mathrm{g} / \mathrm{ml})$, and the resultant peptides were analysed by electrophoresis on a $15 \%$ polyacrylamide gel in the presence of SDS (Cleveland et al., 1977). The peptides were detected by silver staining. The $M_{\mathrm{r}}$ values of protein standards are given on the left of the gels.

pig proteins were consistent with their highly similar amino acid compositions (Table 1). The two proteins also gave very similar one-dimensional peptide maps after digestion with Pronase (Fig. 6). Taken together, the data indicate that the $68000-M_{\mathrm{r}}$ protein has been highly conserved between the two species studied. For further characterization of the purified $68000-M_{\mathrm{r}}$ protein, only the protein from human lymphoblastoid cells was used.

$\mathrm{Ca}^{2+}$ binding

The involvement of $\mathrm{Ca}^{2+}$ in the association of the $68000-M_{\mathrm{r}}$ protein with the $20 \mathrm{k}$ pellet, although at relatively high concentrations $(10 \mu \mathrm{M})$, prompted the examination of the interaction of the isolated protein with $\mathrm{Ca}^{2+}$. Binding studies with ${ }^{45} \mathrm{Ca}^{2+}$ showed that the $68000-M_{\mathrm{r}}$ protein bound $\mathrm{Ca}^{2+}$ with a stoichiometry of approx. $1: 1$ and with a $K_{\mathrm{D}}$ of $1.2 \mu \mathrm{M}$ (Fig. 7). This indicates that there is a single high-affinity $\mathrm{Ca}^{2+}$-binding site on each molecule.

\section{Discussion}

Insolubility in non-ionic detergents has often been used to define 'cytoskeletal' complexes in either whole cells (Osborn \& Weber, 1977; 


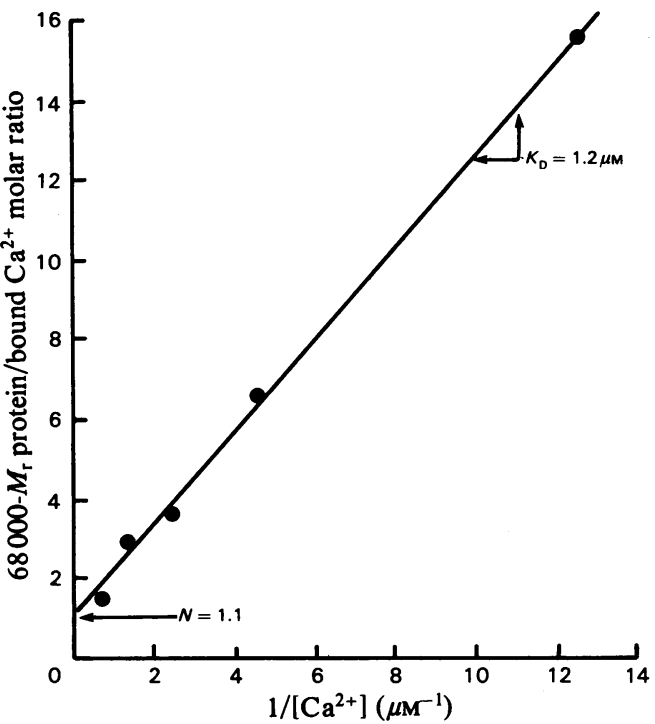

Fig. 7. Measurement of the $\mathrm{Ca}^{2+}-$ binding activity of the $68000-M_{r}$ protein

Samples $(60 \mu \mathrm{g} / \mathrm{ml})$ of the purified $68000-M_{\mathrm{r}}$ protein were incubated with various amounts of ${ }^{45} \mathrm{CaCl}_{2}$ in $10 \mathrm{~mm}-\mathrm{Tris} / \mathrm{HCl}$ buffer, $\mathrm{pH} 7.4$, containing $50 \mathrm{~mm}$ $\mathrm{KCl}$ for $60 \mathrm{~min}$ at $4^{\circ} \mathrm{C}$. The amount of protein-bound ${ }^{45} \mathrm{Ca}^{2+}$ was then measured by the equilibrium gelfiltration method of Hummel and Dryer, as described in the Materials and methods section.

Sheterline \& Hopkins, 1981) or subcellular fractions (Bretscher \& Weber, 1980a,b; Luna et al., 1981; Mescher et al., 1981). With the use of this criterion, a complex of polypeptides has been identified in association with purified preparations of lymphocyte plasma membrane. The functional significance of this complex is unclear, though it seems possible that it represents some form of membrane 'cytoskeleton'. A major component of this detergent-insoluble complex is a $68000-M_{\mathrm{r}}$ polypeptide. This polypeptide accounts for approx. $17 \%$ of the total protein of the complex (or about $2.0 \%$ of the plasma-membrane protein) (Davies et al., 1984). In the present paper the purification and partial characterization of this polypeptide from human and pig lymphocyte plasma membranes has been described. It is a monomeric protein, and by a number of biochemical criteria, including amino acid composition and peptide mapping, the human and pig $68000-M_{\mathrm{r}}$ proteins appear to be homologous. Such a high degree of conservation is characteristic of intracellular proteins, particularly those associated with the cytoskeleton, e.g. actin (Vandekerckhore \& Weber, 1978), tubulin (Ponstingl et al., 1981; Valenzuela et al., 1981) and calmodulin (Klee et al., 1980).
The properties of the $68000-M_{\mathrm{r}}$ protein from lymphocyte plasma membrane indicate that it is distinct from another cytoskeleton-associated protein of the same $M_{\mathrm{r}}$. A major component of the brush-border cytoskeleton of intestinal epithelial cells is a $68000-M_{\mathrm{r}}$ protein, named fimbrin. This protein is also present in several cultured cells, e.g. chick-embryo fibroblasts (Bretscher \& Weber, $1980 b$ ). Fimbrin, however, differs from the lymphocyte $68000-M_{\mathrm{r}}$ protein in terms of amino acid composition and apparent isoelectric point (Glenney et al., 1981). In addition, although fimbrin also binds $\mathrm{Ca}^{2+}$, it is released from the detergent-insoluble fraction of brush-border microvilli by the addition of $\mathrm{Ca}^{2+}$ rather than by depleting $\mathrm{Ca}^{2+}$, as in the case of the lymphocyte protein.

The association of the $68000-M_{\mathrm{r}}$ protein with the detergent-insoluble fraction of the lymphocyte plasma membrane depends on concentrations of $\mathrm{Ca}^{2+}$ in the extraction buffer of greater than $10 \mu \mathrm{M}$. This appears to be rather high for a physiological interaction, since cellular concentrations of free $\mathrm{Ca}^{2+}$ are estimated to be approx. $0.1 \mu \mathrm{M}$ (Kretsinger, 1979). However, it is possible that the $\mathrm{Ca}^{2+}$ concentrations in the extraction buffers do not reflect the actual concentrations of $\mathrm{Ca}^{2+}$ involved in the interaction of the $68000-M_{\mathrm{r}}$ protein with the plasma membrane in vivo. In support of this is the observation that the $68000-M_{\mathrm{r}}$ protein is present in purified plasma-membrane fractions prepared from cells that have been homogenized in buffers containing physiological concentrations of $\mathrm{Ca}^{2+}$. The basis of this discrepancy is not clear, although Walker (1982) showed that similar high concentrations of $\mathrm{Ca}^{2+}$ were involved in the interaction of another putative $\mathrm{Ca}^{2+}$-binding protein, calelectrin, with synaptic membranes in vitro.

The isolated $68000-M_{\mathrm{r}}$ protein appears to have a single $\mathrm{Ca}^{2+}$-binding site, which becomes occupied at micromolar concentrations of $\mathrm{Ca}^{2+}$. This concentration of free $\mathrm{Ca}^{2+}$ corresponds to that associated with the onset of many $\mathrm{Ca}^{2+}$-mediated processes in cells (Kretsinger, 1979). Thus the $\mathrm{Ca}^{2+}$-binding activity of the $68000-M_{\mathrm{r}}$ protein is compatible with a role for the protein as an intracellular $\mathrm{Ca}^{2+}$ receptor. Although calmodulin is considered to be the major $\mathrm{Ca}^{2+}$-dependent regulator in cells, there is evidence for the existence of a number of other intracellular $\mathrm{Ca}^{2+}$ receptors. These include the S100 group of proteins found in neural tissues and the intestinal vitamin $D$ dependent $\mathrm{Ca}^{2+}$-binding proteins (Van-Eldik et al., 1982). Both these proteins have small $M_{\mathrm{r}}$ values, approx. 10000 and 28000 respectively. Recently, a number of polypeptides have been identified in cellular extracts of various tissues, including brain, smooth muscle and striated 
muscle, which co-purified with calmodulin on phenothiazine affinity columns (Moore \& Dedman, 1982). These polypeptides had $M_{\mathrm{r}}$ values of $67000,34000,30000$ and 11000 and were shown to interact directly with antipsychotic drugs in a $\mathrm{Ca}^{2+}$-dependent manner. It was suggested that these polypeptides were functionally analogous to calmodulin in that they formed hydrophobic drugbinding sites as a result of their interaction with $\mathrm{Ca}^{2+}$. The similarity of the $M_{\mathrm{r}}$ values of three of these polypeptides and those associated with the lymphocyte plasma membrane is striking. Although the evidence is highly circumstantial, it is conceivable that the lymphocyte $68000-M_{\mathrm{r}}$ protein is the same as the $67000-M_{\mathrm{r}}$ protein identified by Moore \& Dedman (1982) and that it is representative of a novel class of $\mathrm{Ca}^{2+}$ regulators whose function is, as yet, unknown. The association of the protein with a putative plasma-membrane-cytoskeleton complex, presumably on the cytoplasmic face of the membrane, would make it an attractive candidate for mediating cellular processes for which a regulatory role for $\mathrm{Ca}^{2+}$ and the cytoskeleton has been inferred.

We are grateful to Dr. M. J. Geisow for advice on the preparation of calcium buffers, and Mr. G. T. Scrace for assistance with the amino acid analyses.

\section{References}

Ackers, G. K. (1973) Methods Enzymol. 27, 441-455

Branton, D., Cohen, C. M. \& Tyler, J. (1981) Cell (Cambridge, Mass.) 24, 24-32

Bretscher, A. \& Weber, K. (1980a) Cell (Cambridge, Mass.) 20, 839-847

Bretscher, A. \& Weber, K. (1980b) J. Cell Biol. 86, 335340

Burridge, K. \& Feramisco, R. J. (1981) Nature (London) 294, 565-567

Cleveland, D. W., Fischer, S. G., Kirschner, M. W. \& Laemmli, U. K. (1977) J. Biol. Chem. 252, 1102-1106

Crumpton, M. J. \& Snary, D. (1974) Contemp. Top. Mol. Immunol. 3, 27-56

Davies, A. A., Wigglesworth, N. M., Allan, D., Owens, R. J. \& Crumpton, M. J. (1984) Biochem. J. 219, 301308

Dedman, J. R., Brinkley, B. R. \& Means, A. R. (1979) Adv. Cyclic Nucleotide Res. 11, 131-174

Fowler, V. M. \& Taylor, D. L. (1980) J. Cell Biol. 85, 361376

Glenney, J. R. \& Weber, K. (1980) J. Biol. Chem. 255, 10551-10554
Glenney, J. R., Bretscher, A. \& Weber, K. (1980) Proc. Natl. Acad. Sci. U.S.A. 77, 6458-6462

Glenney, J. R., Kaulfus, P., Matsudaira, P. \& Weber, K. (1981) J. Biol. Chem. 256, 9283-9288

Glenney, J. R., Glenney, P. \& Weber, K. (1982) Proc. Natl. Acad. Sci. U.S.A. 79, 4002-4005

Haga, T., Abe, T. \& Kurokawa, M. (1974) FEBS Lett. 39, 291-295

Howe, C. L., Mooseker, M. S. \& Graves, T. G. (1980) J. Cell Biol. 85, 916-923

Jones, B. N., Paabo, S. \& Stein, S. (1981) J. Liq. Chromatogr. 4, 565-573

Kim, Y. S. \& Padilla, G. M. (1978) Anal. Biochem. 89, 521-528

Klee, C. B., Crouch, T. H. \& Richman, P. G. (1980) Annu. Rev. Biochem. 49, 489-515

Kretsinger, R. H. (1979) Adv. Cyclic Nucleotide Res. 11, $1-26$

Laemmli, U. K. (1970) Nature (London) 227, 680-685

Lowry, O. H., Rosebrough, N. J., Farr, A. L. \& Randall, R. J. (1951) J. Biol. Chem. 193, 265-275

Luna, E. J., Fowler, V. M., Swanson, J., Branton, D. \& Taylor, D. L. (1981) J. Cell Biol. 88, 396-409

Mescher, M. F., Jose, M. J. \& Balk, S. P. (1981) Nature (London) 289, 139-144

Moore, P. B. \& Dedman, J. R. (1982) J. Biol. Chem. 257, 9663-9667

Morrissey, J. H. (1981) Anal. Biochem. 117, 307-310

O'Farrell, P. H. (1975) J. Biol. Chem. 250, 4007-4021

Osborn, M. \& Weber, K. (1977) Exp. Cell Res. 106, 339349

Owen, M. J., Barber, B. H., Faulkes, R. A. \& Crumpton, M. J. (1980) Biochem. J. 192, 49-57

Owens, R. J. \& Crumpton, M. J. (1983) Biochem. Soc. Trans. 11, 156-157

Ponstingl, H., Krauhs, E., Little, M. \& Kempf, T. (1981) Proc. Natl. Acad. Sci. U.S.A. 78, 2757-2761

Rosenberg, S., Stracher, A. \& Burridge, K. (1981). J. Biol. Chem. 256, 12986-12991

Schliwa, M. (1976) J. Cell Biol. 70, 527-540

Sheterline, P. \& Hopkins, C. R. (1981) J. Cell Biol. 90, 743-754

Snary, D., Woods, F. R. \& Crumpton, M. J. (1976) Anal. Biochem. 74, 457-465

Valenzuela, P., Quiroga, M., Zaldivar, J., Rutter, W. J., Kirschner, M. W. \& Cleveland, D. W. (1981) Nature (London) 289, 650-655

Vandekerckhore, J. \& Weber, K. (1978) Proc. Natl. Acad. Sci. U.S.A. 75, 1106-1110

Van-Eldik, L. J., Zendegui, J. G., Marshak, D. R. \& Watterson, D. M. (1982) Int. Rev. Cytol. 77, 1-61

Walker, J. H. (1982) J. Neurochem. 39, 815-823

Weisenberg, R. C. (1972) Science 177, 1104-1105

Yin, H. L. \& Stossel, T. P. (1981) Nature (London) 281, 583-586 